\title{
In Memoriam: Maxwell John Charlesworth
}

\author{
Patrick Hutchings
}

Published online: 17 December 2014

(C) Springer Science+Business Media Dordrecht 2014

Maxwell John Charlesworth, cofounder with Graeme E. de Graaff, of Sophia (1962), died suddenly and peacefully at home on the second of June 2014. Born on the thirtieth of December 1925 in Numurkah, Victoria, Max took his MA in Philosophy at the University of Melbourne in 1948. At that time, the Melbourne Department of Philosophy was the preeminent school in Australasia. He married Stephanie Armstrong in 1950. Between 1950 and 1952, he was hospitalized for TB. On his recovery, he studied - 1953-1955 - at the University of Louvain, where he took his $\mathrm{PhD}$ avec la plus grande distinction. He was later to become Visiting Professor at the Katholieke Universiteit Leuven in 1972 and 2006. In 1956, he was appointed to a lectureship at the University of Auckland, New Zealand and returned to a position in his old University of Melbourne in 1959.

A man of wide and deep interests, Max worked in the fields of Bioethics and Anthropology, as well as in Philosophy. He was a visiting Professor at the Maison des Sciences de l'Homme in Paris in 1980. His interest in politics and social justice had had him a co-founder of The Catholic Worker 1948-1965. Following Vatican II Max was, in 1970, appointed to the Vatican's Secretariat for Non-Believers: this, ironically, followed his friction with "the mind of the Archbishop"-His Grace the redoubtable Daniel Mannix - over the moderately radical Catholic Worker.

Having been a Nuffield Fellow at the Warburg Institute, London, 1963-1964 and Visiting Professor at the University of Notre Dame, Indiana USA, 1968-1969, Max became Chairman of the University of Melbourne, Department of Philosophy from 1974 to 1975.

In 1975, Max Charlesworth became the Foundation Dean of Humanities at the new Deakin University at Geelong. Here, his interests in social justice, education, and general cultural activities flowered. Deakin was loosely modeled on the UK's Open University. Like the OU, Deakin was an open-entry institution which attracted many mature age students and which offered a number of new and experimental interdisciplinary courses.

Between 1987 and 1990, Max Charlesworth was the Chairman of the Advisory Committee at the Centre for Human Bioethics.

\footnotetext{
P. Hutchings $(\bowtie)$

School of Historical and Philosophical Studies, University of Melbourne, Melbourne, Australia e-mail: sophia@philosophy.unimelb.edu.au
} 
Upon his retirement from Deakin in 1990, Max Charlesworth became Director of the National Institute for Law, Ethics and Public Affairs at Griffiths University in Queensland, 1992-1994.

In 1991, Maxwell John Charlesworth was made an officer of the Order of Australia for his distinguished services as a public intellectual.

Max Charlesworth was buried from the chapel of his old College, Newman, in the University of Melbourne. There was a standing room only in the elegant neo-Gothic nave. The Liturgy was full of the hope and expectation of Eternal Life, the presiding priests in white vestments, the hymns triumphant.

Max is remembered by the editorial team of Sophia both as the journal's co-founder, and for many and particular kindnesses to them as individuals.

May he rest in peace.

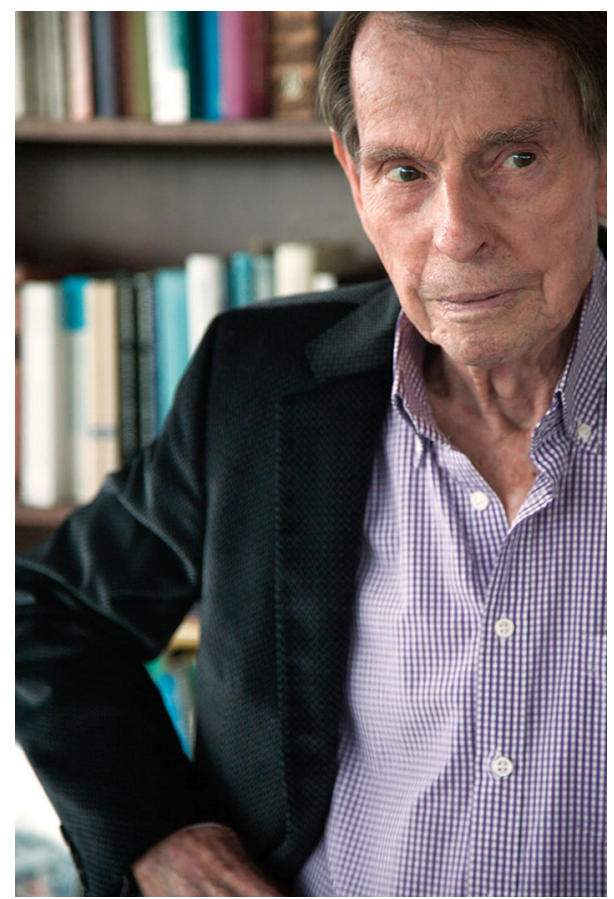

Max Charlesworth in front of his library. Photo by Max's granddaughter Leila Koren 